\section{Über das Mittelalter}

Friedrich Schlegel sieht in seiner Charakteristik des mittelalterlichen Geistes das negative Moment dieser Epoche in der herrscheden unbeschränkten Richtung auf das Absolute, die sich in der Kunst als gezierte Phantasie, in der Philosophie und Theologie der Scholastik als ein nicht minder gezierter Rationalismus geltend macht. Das soll durch den Kontrast gegen die asiatische Geistesrichtung noch etwas ausgeführt werden. Auch der asiatische Geist ist durch eine hemmungslose Versenkung in das Absolute in Philosophie und Religion bezeichnet. Dennoch trennt inn vom mittelalterlichen Geiste ein Abgrund. Ihm liegt bei äusserster Formgrösse nichts ferner als Geziertheit. Seine innerste Verschiedenheit vom Geiste des Mittelalters beruht darin, dass er das Absolute, aus dem er die Sprache entfaltet, als gewaltigsten Inhalt

\section{Sobre a Idade Média}

Ronaldo Marcos Simões Moreira

Friedrich Schlegel vê em sua "Característica do Espírito Medieval" o momento negativo da idade média em sua tendência dominante de busca obstinada pelo absoluto, tendência esta que se impôs no campo das artes como fantasia falseada e no âmbito da filosofia e da teologia escolástica como um racionalismo não menos falseado. Isto deve ser explanado mais amiúde em contraste com a orientação espiritual asiática. Da mesma forma, o espírito asiático é caracterizado pela sua descontrolada imersão no absoluto nos campos da filosofia e da religião. Entretanto, um abismo separa-o do espírito medieval. No tocante à dimensão de sua forma mais externa, não resta-lhe nada mais do que falseabilidade. Sua diferença mais recôndita do espírito medieval consiste que esse tem o absoluto, do qual ele desenvolve a linguagem de sua forma, como essência presente mais poderosa. $O$ espírito 


\begin{tabular}{|c|c|}
\hline $\begin{array}{l}\text { telalter die Religion das Leben } \\
\text { terrschte. Aber erstens war die } \\
\text { rscherin die Ekklesia und zweitens } \\
\text { let zwischen herrschendem und }\end{array}$ & $\begin{array}{l}\text { oriental dispõe das verdadeiras } \\
\text { essências do absoluto, o que já se } \\
\text { evidencia no conjunto religião-filosofia- } \\
\text { arte, mas, principalmente, } \\
\text { entrelaçamento da religião com vida. } \\
\text { Falou-se muito, que a religião dominava } \\
\text { a vida na idade média. Mas, inicialmente, } \\
\text { a dominadora foi a "ekklesia" e, } \\
\text { posteriormente, já ocorre uma separação } \\
\text { entre princípio dominante e dominado. É } \\
\text { mesmo sobretudo característico do } \\
\text { espírito da idade média sua tendência ao } \\
\text { absoluto, e, quanto mais radical esta } \\
\text { tendência se manifesta, ao mesmo } \\
\text { tempo, mais formal ela fica. A } \\
\text { hipermitológica hereditariedade da } \\
\text { antiguidade ainda não se perdeu, mas }\end{array}$ \\
\hline
\end{tabular}




\begin{tabular}{|c|c|}
\hline die & $\begin{array}{l}\text { campo da química; a magia da } \\
\text { antiguidade utiliza as coisas da natureza } \\
\text { para fazer suas poções mágicas e } \\
\text { unguentos que possuem relação } \\
\text { determinada com o mitológico reino } \\
\text { natural. Mas o que é que na verdade o } \\
\text { alquimista procura por caminhos } \\
\text { mágicos? O ouro - de forma análoga, } \\
\text { isso acontece também com a arte. Ela } \\
\text { nasce com o ornamento do místico. O } \\
\text { ornamento asiático é mitologicamente } \\
\text { saturado e o ornamento gótico se tornou }\end{array}$ \\
\hline
\end{tabular}




\begin{tabular}{|c|c|}
\hline $\begin{array}{l}\text { Grössenmassstab nach kleiner gezirkelter } \\
\text { als die Antike, auch als die unsere, } \\
\text { gewesen ist. Im höchsten Mittelalter war } \\
\text { die antike Weltansicht endlich in hohem } \\
\text { Masse vergessen, und in dieser } \\
\text { verkleinerten Welt, die blieb, ist der } \\
\text { scholastische Rationalismus und die } \\
\text { selbst verzehrenden Sehnsucht der Gotik } \\
\text { entsprugen. } \\
\text { BENJAMIN, Walter. Aufsätze, Essays, } \\
\text { Vorträge - Gesammelte Schriften, } \\
\text { Band II-1 Frankfurt am Main: Suhrkamp } \\
\text { Taschenbuch Wissenschaft, } \\
\text { Seiten. 132-133 }\end{array}$ & $\begin{array}{l}\text { certeza de acordo com seu absoluto } \\
\text { padrão exuberante - menor do que a } \\
\text { visão de mundo da antiguidade e } \\
\text { também menor do que a nossa. Na } \\
\text { altíssima idade média, a visão de mundo } \\
\text { da antiguidade foi finalmente, em grande } \\
\text { parte, esquecida, e, neste mundo } \\
\text { diminuído que restou, nasceu o } \\
\text { racionalismo escolástico e a sua } \\
\text { ansiedade autofágica pelo gótico. }\end{array}$ \\
\hline
\end{tabular}

